Betyr Hizbullahs nedtoning av målet om en islamsk stat i Libanon at organisasjonen har slått inn på en pluralistisk kurs? Ikke nødvendigvis. Det finnes flere andre grunner, både $\mathrm{i}$ fortida og nåtida, til at dette målet ikke lenger framheves av Hizbullah.

\title{
Fra motstandsbevegelse til ... hva?
}

HIZBULLAHS POLITISKE ROLLE I LIBANON

Kai Kverme er masterstudent ved Universitetet i Oslo og forskningsassistent på prosjektet Fault Lines of Islamism: Negotiating Progress, Participation and Patriarchy ved samme universitet. 
TEKST: Kai Kverme

EN MYE BRUKT DEFINISJON når man definerer en politisk bevegelse som islamistisk, er at man fra bevegelsens side søker å forandre staten til å opptre og lovgi i samsvar med "sharia", den islamske loven, selv om det ofte fremstår som uklart hva dette konkret innebærer. Men enkelte bevegelser som man uten tvil vil kalle islamistiske, har tilsynelatende forlatt eller utsatt dette målet. Hizbullah i Libanon er en av disse.

Forklaringen organisasjonen selv gir på hvorfor dette ansees for nødvendig, henger sammen med det faktum at Libanon er en stat med i8 forskjellige religiøse sekter som er offisielt godkjent, og at ingen av disse sektene har oppslutning nok til å alene dominere de andre. "Det er ingen tvang i islam, vi ønsker ikke å tre en islamsk stat ned over hodet på noen som ikke ønsker det”, er det fremste argument- et fra Hizbullahs side når de skal forklare at målet om en islamsk stat er lagt på is. ${ }^{1}$ Men er dette den viktigste grunnen? I det følgende vil jeg foreslå noen alternative årsaker gjennom en analyse av Hizbullahs tilblivelse og utvikling fram til i dag.

Like lite som andre bevegelser og grupper oppstod Hizbullah i et vakuum. Selv om det var den israelske invasjonen av Libanon i I982 som var den direkte årsaken til at gruppen ble opprettet, hadde man i mange år sett et voldsomt oppsving i den politiske deltagelsen fra libanesiske shiaers side, på et religiøst grunnlag.

I likhet med de andre sektene var shiaene tradisjonelt representert av foydalherrer, som ikke nødvendigvis hadde befolkningens ve og vel i høysetet, men som snarere handlet ut fra egne interesser og ønsket om å beholde sin egen posisjon i den nye staten. Dette representasjonsmønsteret fortsatte også etter at Libanon ble uavhengig i I943, men utover femti- og ikke minst sekstitallet økte den politiske bevisstheten blant shiaene, og en større del av dem ble politisk aktive. Det så ut til at et flertall av dem var aktive i forskjellige venstreorienterte partier og grupper, en utvikling man også fant blant shiaene i for eksempel Irak. På slutten av femti- og utover sekstitallet oppstod det imidlertid grupper som organiserte seg med basis i religionen, den fremste og mest innflytelsesrike av disse var Da'wa-partiet som ble dannet i Irak rundt I958. I Libanon begynte forandringene med at en ung 'alim ble bedt om å komme til Tyr for å lede shiaene der.

\section{Musa al-Sadr}

Musa al-Sadr var født i Iran, men hadde libanesisk familiebakgrunn og startet nesten umiddelbart arbeidet med å etablere seg 
selv som lederen for de libanesiske shiaene. Dermed brøt han det maktmonopolet de etablerte føydalfamiliene frem til da hadde hatt, noe som økte hans anseelse blant massene av shiaer, som for en stor del stod utenfor det økonomiske oppsvinget landet opplevde på femti- og sekstitallet. AlSadr så det som en viktig oppgave å få den libanesiske staten til å ta på alvor problemene med manglende utbygd infrastruktur, fattigdom og manglende representasjon som gjorde seg gjeldene i sør og i Biqa’a, områder der shiaene var i flertall. Han lyktes i dette på noen områder, ikke minst når det gjaldt å inkludere shiaene sterkere i de politiske prosessene i landet. Men samtidig pågikk det en utvikling i retning av en stadig økende polarisering av befolkningen mellom dem som ønsket en omfordeling

Khomeinis idé stipulerer at det er de skriftloerdes oppgave å lede den muslimske nasjonen både politisk og religiøst.

av ressursene i landet og politiske reformer med sikte på en jevnere fordeling av makten, og dem som ønsket å opprettholde status quo. Skillelinjene gikk heller ikke på det tidspunktet mellom kristne på den ene siden og muslimer på den andre, men konflikten antok et stadig tydeligere sekterisk preg på begynnelsen av syttitallet.

Musa al-Sadrs viktigste bidrag lå $i$ at han politiserte massene av libanesiske shiaer og forsøkte å mobilisere dem rundt hva han anså for å være en autentifisert utgave av shia islam, med vekt på sosial utjevning og politiske reformer.
Musa al-Sadr forsvant under et besøk til Libya i I978, og hans skjebne er fremdeles uklar, men radikaliseringen av shiaene som han initierte fortsatte, og to andre begivenheter kort etter hans forsvinning akselererte denne utviklingen. Israel invaderte Libanon for første gang, med det mål for øye å drive de palestinske geriljakrigerne lenger nord og sikre sin egen grense. Men viktigere enn dette var begivenheter som utspant seg i al-Sadr's fødeland Iran, der en revolusjon brøt ut i begynnelsen av I979, som endte med at man opprettet en islamsk republikk under ledelse av Ayatullah Khomeini.

\section{Betydningen av Najaf-miljøet}

Khomeini hadde vært i eksil i Najaf i Irak siden midten av sekstitallet, på denne tiden det udiskutable senteret for shiaislam. Der hadde han utviklet en teori omkring islamsk styre, som kort fortalt innebærer at det er ulama, de skriftlærde, sin rolle å styre samfunnet både politisk og religiøst. Denne teorien, wilayat al-faqih, den rettslærdes styre, ble senere statsbærende i Iran, men fikk også en rekke tilhenger blant shiaer fra andre deler av verden, ikke minst Libanon.

Mange unge shiaer hadde nemlig reist fra Libanon til Najaf for å skaffe seg en religiøs utdannelse. Flere av dem var fremtredende medlemmer av Afwâj alMuqâwmat al-Lubnâniyya (AMAL), en militær bevegelse grunnlagt i I975, men også en annen, og til dels overlappende, innflytelse hadde begynt å gjøre seg gjeldende blant radikaliserte shiaer.

Muhammad Husayn Fadlallah, som fremdeles er en av de viktigste shiamuslimske lærde i Libanon. Han er opprinnelig fra Irak, men som Musa al-Sadr 
hadde han nære familiære bånd til Libanon. Han hadde studert en årrekke i Najaf og var en del av den kretsen som stiftet Da'wa-partiet. I Libanon konsentrerte Fadlallah seg i større grad enn al-Sadr om intellektuelt arbeid. Hele tiden beholdt han nær kontakt med Najaf og de unge libaneserne som dro dit, og flere av dem ble etter hvert medlemmer av Da'wa-partiet, blant dem Hizbullahs nåværende generalsekretær Hasan Nasrallah. ${ }^{2}$

\section{Splittelse i AMAL}

Situasjonen i hele Midtøsten forandret seg etter revolusjonen i Iran, og de libanesiske studentene måtte dra hjem igjen. Der begynte de å organisere støttegrupper for revolusjonen, med Fadlallah som ivrig deltager og åndelig veileder. Internt i AMAL førte dette til at splittelsen mellom de radikale delene som støttet revolusjonen, og de delene som var mer avventende og kritiske, økte.

Nabih Birri hadde overtatt som leder for AMAL etter al-Sadr, og han representerte en helt annen del av shiaene enn de unge studentene. Birri var en typisk representant for den stadig voksende gruppen av middelklasse-shiaer, født i Sierra Leone av foreldre som hadde emigrert dit for å unnslippe den trøstesløse økonomiske situasjonen i Sør-Libanon, utdannet advokat og tidligere medlem av den pro-syriske delen av Ba'th-partiet. ${ }^{3}$ Det var Birris vilje til å inngå kompromisser med andre libanesiske politikere i kjølvannet av den israelske invasjonen som ble utslagsgivende for at flere grupper brøt ut av bevegelsen og dannet det som ble til Hizbullah.

En rekke religiøse studenter, blant dem Hasan Nasrallah og Abbas al-Mussawi, var ikke selv i Libanon da israelerne invaderte, de var i Teheran. Der var de sammen med Fadlallah for å delta på en større konferanse for islamske bevegelser, og her ble de instruert av Khomeini til å dra tilbake til Libanon og grunnlegge en organisasjon på "rene islamske prinsipper". ${ }^{4}$

\section{Styrende prinsipper}

Med dette var grunnlaget på plass for det nye partiet, og de to førende prinsippene man stadig bygger på ble knesatt. Det første er prinsippet om motstand, muqawama, først og fremst mot den israelske invasjonen, men også i videre forstand, mot Israel, USA og Vesten generelt, samt mot den libanesiske staten, som man anså for å være både uislamsk og "skapt av vestlig imperialisme for å ødelegge muslimenes karakter i Libanon og vestliggjøre det". ${ }^{5}$ Hizbullahs motstand er en del av en større jihad, hvis overordnede mål er opprettelsen av en islamsk orden. Mens det siste målet er tonet kraftig ned, er det motstanden som er det fremste kjennetegnet for partiets politiske fremtoning.

De første motstandsaksjonene ble utført flere år før partiet offisielt hadde bekjentgjort sin eksistens, under paraplyen til en løs sammenslutning av forskjellige grupper og bevegelser kalt LNR, Lebanese National Resistance, som var under syrisk ledelse. Først i I984 dannet partiet Den islamske motstanden (al-Muqawama alislamiyya) som fremdeles er deres væpnede gren.

Det andre av disse prinsippene var og er selve bærebjelken i partiet, Khomeinis idé om wilayat al-faqih, som stipulerer at det er de skriftlærdes oppgave å lede den muslimske nasjonen, ummaen, både politisk og religiøst i fraværet av den skjulte imamen. Ifølge den er det også en nød- 
vendighet å etablere en islamsk orden, et mål det ikke er noe rom for å forlate, siden det er et religiøst sanksjonert krav. ${ }^{6}$

Wilayat al-faqih plasserer Hizbullah i en religiøs sammenheng, og gir bevegelsen en helhetlig ideologi å arbeide ut ifra. På mange måter er det en elitistisk idé, i og med at den plasserer de geistlige på toppen av samfunnspyramiden som fortolkere og forvaltere av religionen, noe man anser at den menige muslim verken har intellektuell eller moralsk kapasitet til å forestå. ${ }^{7} \mathrm{Her}$ finner vi et nøkkelpunkt for forståelsen av hvordan Hizbullah tenker og handler - det er denne ideologien som legger premissene for partiet som politisk aktør, og også for hvordan de selv er organisert.

I henhold til denne ideologien er det faqihen som er den øverste lederen, ikke bare over partiet, men generelt over den muslimske umma. Det er han som tar beslutninger om krig og fred, han har absolutt makt til å forme og forandre ideologien og bestemme hvordan den skal gjennomføres. Å følge hans påbud og forordninger er ansett som en religiøs plikt, og det er Hizbullahs ansvar å sette disse ut i livet. Det betyr ikke at partiet er detaljstyrt av faqihen, snarere har ideologien gitt partiet mulighet for å opptre meget pragmatisk når omstendighetene har krevet det. Faqihen kan også gi partiet mulighet til å forandre eller omdefinere dets politikk dersom det skulle være noe som nødvendiggjør det.

Et eksempel på hvordan dette fungerer $\mathrm{i}$ praksis fikk vi etter Ta'if-avtalen, som i I990 avsluttet den libanesiske borgerkrigen - en avtale Hizbullah var imot, men som førte til at partiet måtte revurdere sin tidligere strategi om å styrte staten. Flertallet av medlemmene i Majlis al-shura, parti- ets øverste styringsorgan, mente at man burde delta i de kommende valgene på ny nasjonalforsamling, ikke fordi man hadde forandret syn på systemet, men for å gi motstandsbevegelsen økt legitimitet og for å bruke parlamentets talerstol til å fremme sitt eget syn. Dette synet ble avvist av et mindretall, som mente det var uakseptabelt å delta i valgene siden man anså at dette ville legitimere et uislamsk system. Saken ble forelagt faqihen, den øverste iranske lederen ayatullah Khamene'i, som sanksjonerte partiets deltagelse i valgene. Dermed begynte det man fra partiets side kalte den politiske jihad.

Hizbullahs deltagelse i valgene og deres bevegelse bort fra en konfrontasjonslinje i retning en pragmatisk samarbeidslinje har av mange forskere blitt sett på som et totalt skifte i partiets ideologi, fra milits til regulært parti. ${ }^{8}$ Dette bygger etter min mening på en manglende forståelse av partiets ideologiske forankring og de mulighetene som den potensielt innebærer, i tillegg til den innflytelse utenlandske makter har på den politiske situasjonen i Libanon. De siste års hendelser i regionen styrker en slik oppfatning, siden utviklingen viser en islamistisk organisasjon som har manøvrert seg fram til å bli en helt sentral politisk kraft i Libanon som står på flere bein.

\section{Pax Syriana}

Situasjonen etter avslutningen av borgerkrigen var først og fremst kjennetegnet ved Syrias totale makt over Libanon og landets politiske prosesser. Syria hadde interesse av å opprettholde Hizbullah som en militær faktor av flere årsaker, ved å ha flere maktsentra kunne man spille disse mot hverandre og slik opprettholde egen makt som pressmiddel i forhold til Israel, ikke 
minst på grunn av forholdet til Iran, Syrias nøkkelallierte i regionen. Ved avslutningen av krigen fremstod Hizbullah som den suverent sterkeste militsen i landet. Etter harde kamper med AMAL, som kun ble avsluttet som følge av direkte syrisk/iransk innblanding, hadde man klart å redusere denne organisasjonens innflytelse kraftig. Syria ga Hizbullah det handlingsrommet de trengte for å fortsette den væpnede kampen mot Israel, og til gjengjeld kunne syrerne fortsette sin egen økonomiske

\section{rom \\ Israels tilbaketrekking fra Sør- Libanon i 2000 representerte høyde- punktet for Hizbullahs innflytelse.}

utnyttelse av Libanon uten at Hizbullah satte seg for sterkt til motverge. Den tiltagende korrupsjonen og andre forhold ble kritisert i klare ordelag, men partiet utfordret ikke den politiske makten, og dermed Syria, og fortsatte å arbeide innenfor de eksisterende strukturene.

Israels ensidige tilbaketrekking fra SørLibanon i 2000 representerte høydepunktet for Hizbullahs innflytelse i Libanon. Selv om andre forhold også spilte en rolle i tilbaketrekkingen, var de stadige aksjonene fra Hizbullah den utslagsgivende faktoren. Den nye virkeligheten representerte imidlertid en utfordring for partiet, siden dets viktigste mål nå tilsynelatende var oppnådd: Med unntak av et lite område ved Shib'a-området helt sør i Libanon var tilbaketrekkingen total. Aktivitetene ble nå vendt mot dette området, mens man politisk konsentrerte seg om å støtte den nye intifadaen som hadde brutt ut i Palestina.
Samtidig begynte kravene fra andre libanesiske politiske aktører å tilta om en avvæpning av Hizbullah, eller innkorporering av partiets væpnede styrker i hæren.

\section{Økende polarisering}

Den politiske situasjonen i Libanon har i de siste årene utviklet seg i retning av en sterk polarisering mellom de gruppene som ønsker en sterkere stat med full autoritet over hele landet, og de som ønsker en desentralisert stat der stor vekt er lagt på tanken om kontinuerlig motstand. Hvilket forhold man ønsker til Syria er også et kjernepunkt i denne polariseringen, og ikke minst spiller ambisjonene og rivaliseringen til forskjellige politiske ledere en avgjørende rolle i denne utviklingen.

Utgangspunktet dreide seg om Syrias innflytelse og makt over de politiske prosessene i landet. Ved utløpet av tidligere president Emile Lahouds periode i 2004 hadde man ikke klart å finne en erstatter alle kunne enes om, og Syria søkte Lahouds periode forlenget med tre år. Lahoud hadde ikke noen egen politisk base i Libanon, han hadde bakgrunn fra hæren og hans styrke kom først og fremst fra det nære forholdet hans til Damaskus. Forlengelsen møtte sterk motstand fra en rekke politiske og religiøse ledere, ikke minst fra statsminister Rafiq Hariri, som lenge hadde hatt et anstrengt forhold til presidenten. Syria valgte likevel å tvinge igjennom en forlengelse, med støtte fra Hizbullah som lenge hadde vært skeptiske til Hariri; de var nå redd han ville støtte en FN-resolusjon som krevde avvæpning av partiet. Bare kort tid etter dette ble Marwan Hamade, en alliert av Hariri og medlem av det Progressive Sosialistpartiet under ledelse av Walid Jounblat, utsatt for et atten- 
tatforsøk. Han overlevde, men få måneder senere ble Hariri selv drept $i$ et voldsomt attentat som hans politiske allierte hevdet Syria stod bak, for å hindre at han skulle bli en lederskikkelse i en fremtidig anti-syrisk allianse. Syria måtte nå etter internasjonalt press trekke seg ut av Libanon, og en attentatkampanje fulgte der flere ledende intellektuelle og politikere med Syria-skeptiske holdninger ble drept.

\section{Alliansen med Aoun}

I denne situasjonen var på mange måter Hizbullah i sitt ess, fordi hele deres eksistens har vært preget av krisesituasjoner. Lederne i partiet så nå sitt snitt til å bringe oppmerksomheten tilbake dit de mener den hører hjemme: mot kampen mot Israel. Sommeren 2006 kunne man derfor observere en krig mellom et parti på den ene siden og en stat på den andre. Problemet nå var at man ikke lenger hadde noen samlet befolkning bak seg, selv om kritikken først og fremst ble rettet mot Israel og deres overdrevne maktbruk. Det ble klart for alle at det ikke var staten som satt med beslutningen om krig eller fred: den beslutningen ble tatt av et parti i samarbeid med Irans øverste leder Ali Khamene'i. Noen måneder etter krigen gikk Hizbullah også ut av samlingsregjeringen de for første gang hadde deltatt $i$, og en politisk og økonomisk boikott av den ble iverksatt. Med seg hadde partiet andre pro-syriske partier og ikke minst Michel Aoun.

Nettopp alliansen med Aoun er et mye brukt argument for at partiet reelt har foretatt et ideologisk skifte og nå ønsker et samarbeid på tvers av sekteriske og ideologiske skillelinjer, siden Aoun er en kristen leder. Men denne alliansen kan også forstås på en annen måte. På den ene siden har man
Aoun, den selverklærte talsmannen for Libanons maronitter som gjennom mange år i eksil i Paris fremstod som den ledende kritikeren av Syrias tilstedeværelse i landet og med et uttalt ønske om å bli president. Konflikter med andre kristne politikere, først og fremst på grunn av personlige, ikke politiske, motsetninger, umuliggjorde dette og etterlot Aoun som en meget bitter mann, forsøkt isolert og tilsidesatt. På den andre siden er Hizbullah, som gjennom alliansen har kunnet vise til at det ikke bare er de tradisjonelt pro-syriske kristne partiene som støtter motstandsbevegelsen, og det uten at partiet selv har måttet inngå noen kompromisser som har rokket ved deres fundament. Slik har det lyktes for partiet å øke legitimiteten for sin motstandsbevegelse blant grupper som tidligere har vært sterkt kritiske mot dem.

\section{Hvor går Hizbullah?}

Tidligere i sommer kom den foreløpig siste og alvorligste konfrontasjonen mellom Hizbullah og dets motstandere, der partiet tok til våpen for å hindre at deres overvåkning av den internasjonale flyplassen i Beirut ble avviklet og for å hindre at partiets kommunikasjonsnettverk kom under statens kontroll. Det gjorde partiet selv om man alltid har sagt at motstandsbevegelsens våpen aldri ville bli brukt mot andre libanesere, og med dette ble det enda en gang demonstrert at det er Hizbullah som er den fremste maktfaktoren i landet, sterkere enn selv den libanesiske hæren.

Hizbullahs videre utvikling er avhengig av en rekke forhold og kan, slik jeg ser det, ta flere forskjellige retninger. Et av forholdene er situasjonen for Libanons shiaer $i$ forhold til politisk representasjon og økonomisk utvikling. På det politiske plan kan 


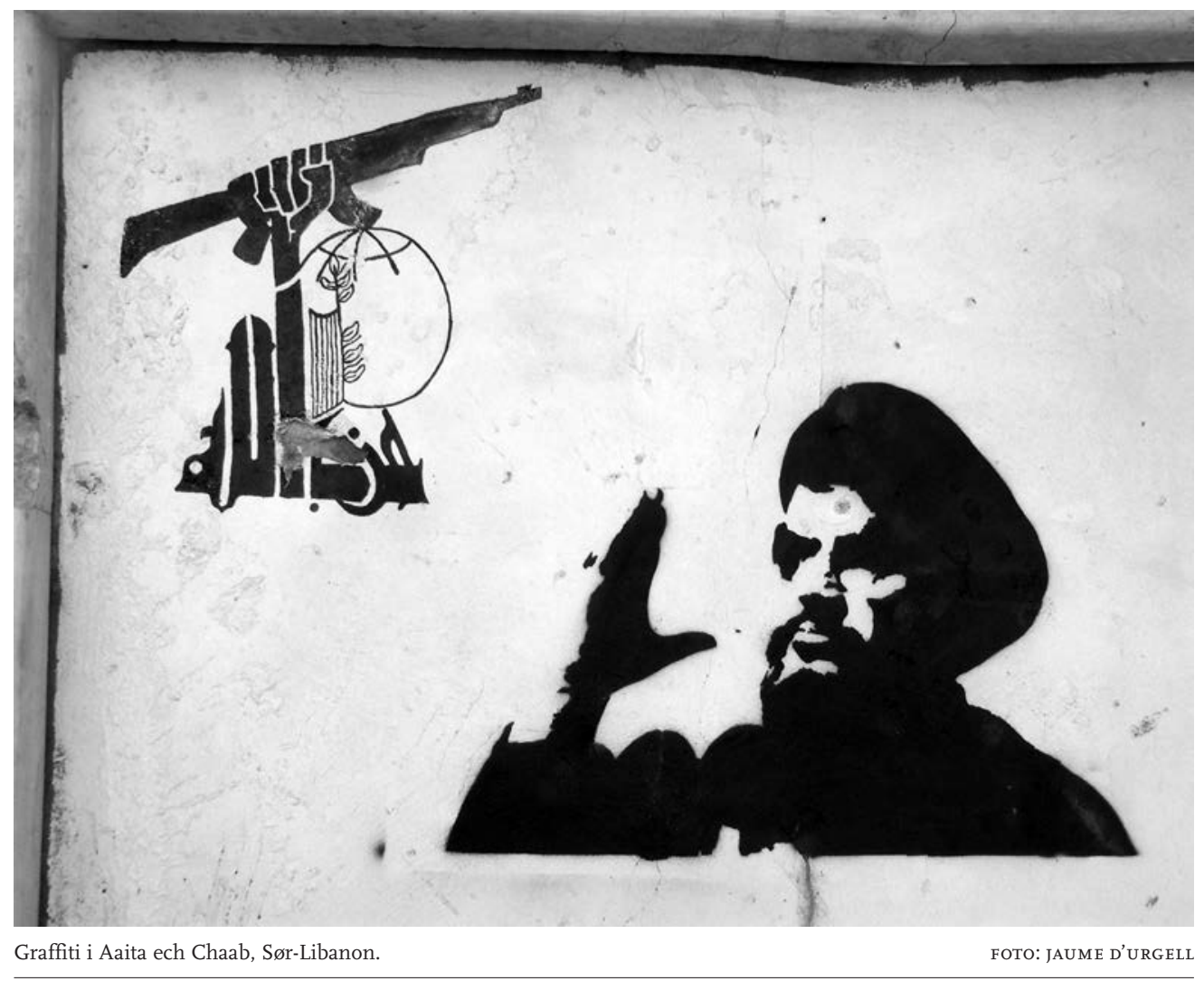

det argumenteres for at utviklingen har kommet veldig langt, og det synes som at de nå har minst like stor innflytelse som de andre sektene. Et eksempel på dette er at det lyktes dem å lamme alt parlamentarisk liv i nærmere et år, ved at parlamentets leder Birri nektet å sammenkalle det. Parlamentets leder skal i henhold til Ta'if-avtalen være en shia, og flere andre fremtredende ministere er også shiaer.

Den stadig tiltagende sekterismen i Libanon vil spille en viktig rolle for Hizbullah, slik den også vil gjøre for andre grupper og partier i landet. Mens skillelinjene under borgerkrigen for en stor del gikk mellom kristne og muslimer, går det nå et skille mellom sunni- og shiamuslimer. Hizbullahs våpenbruk i Beirut var først og fremst rettet mot Hariris sunni-dominerte
Future Movement og Dar al-Fatwa, den høyeste sunniautoriteten i landet. Dette hadde imidlertid den konsekvensen at sunni-politikere som tidligere har stått nærmere Hizbullah så seg nødt til å distansere seg fra partiet, og Future Movement fremstår nå som sunnienes førende representant. Et eksempel på dette fikk vi da en liten salafistisk utbrytergruppe i Tripoli under stort medieoppbud kunngjorde at de hadde inngått en "forståelse" med Hizbullah. Selv om punktene i "forståelsen" ikke var spesielt kontroversielle, ble de etter et knapt døgn tvunget av andre salafistgrupper til å gå tilbake på avtalen, og det ble fra de andre gruppenes side gjort klart at man anså Future Movement for å være sunnienes talerør, og at ingen slik forståelse eller avtale kunne inngås uten deres 
velsignelse. ${ }^{9}$ Hizbullah er også selv i høyeste grad et sekteristisk parti, i den forstand at det er temaer fra shiaislam som blir brukt for å mobilisere, aktivere og ikke minst legalisere partiets politikk overfor massene av libanesiske shiaer. Husayn og Abbas er fremstilt som rollemodeller for motstanden, og for kvinnebevegelsen er

\section{Kvinnene ser sin deltagelse i partiets sosiale arbeid som en del av den samme jihaden som mennene er.}

Zaynab en tilsvarende rollemodell. Kvinnene ser sin deltagelse i partiets sosiale arbeid som en del av den samme jihaden som mennene gjennom motstandsbevegelsen er en del av. $^{\text {io }}$ Selv om Hizbullah er nøye med å understreke at de ikke ser på seg selv som et shia-parti, men som et parti for alle muslimer, gjør deres tilknytning til wilayat al-faqih-doktrinen at veldig få sunnier ser på partiet som en aktuell representant.

Ikke minst vil situasjonen i regionen som sådan ha en stor, kanskje avgjørende innvirkning på Hizbullahs videre utvikling. Dette gjelder særlig utviklingen i Iran og Syria. Syria har vært av uvurderlig betydning for partiet, de ga politisk støtte samtidig som man fra syrisk side anså seg vel tjent med å bruke Hizbullah militært som et pressmiddel mot Israel. Selv om man nå igjen har innledet fredssamtaler med israelerne, er det på ingen måte sikkert at det vil munne ut $i$ en avtale som Syria kan leve med. Partiet er naturligvis motstander av samtalene, fordi en fredsavtale vil komplisere deres stilling i Libanon og muligens gjøre det lettere for andre shia-grupper som AMAL å tre frem som alternativer til Hizbullah.

Men det er utviklingen i og rundt Iran som vil være av størst viktighet. Partiet er gjennom sin tilknytning til Ali Khamene'i som faqih, en del av den samme islamistiske bevegelsen som den islamske republikken. Skulle USA velge å angripe Iran, er det all grunn til å tro at Hizbullah vil bli brukt som en del av et motangrep, mens det på den annen side også er all grunn til å tro at et mer konstruktivt samarbeid med Vesten vil påvirke Hizbullah også. Khamene'i har makt til å forandre partiets politikk, og dersom han ser seg tjent med å omforme partiet er det en reell mulighet for det. Et annet spørsmål som vil måtte forbli ubesvart i dette henseendet, er hvordan Hizbullah vil forholde seg til Khamene'is etterfølger, hvem nå det måtte bli.

\section{Konklusjon}

Som jeg har prøvd å vise lå forholdene meget godt til rette for opprettelsen av en bevegelse som Hizbullah på begynnelsen av I980-tallet, ikke minst på grunn av det arbeidet som Musa al-Sadr hadde gjort for å politisere og mobilisere de libanesiske shiaene. Selv om partiet har motstanden som et av sine overordnede prinsipper, har det utviklet seg til å bli en bevegelse med en struktur som ligner en stats. Ikke minst takket være hjelp fra Iran har man bygget opp denne strukturen, som har gitt veldig mange mennesker en sosial sikkerhet som ikke den libanesiske staten ikke har vært i stand til å tilby sine innbyggere. Om dette er en del av den islamske orden Hizbullah ideelt sett ønsker å etablere, eller om det er et svar på statens manglede evne eller vilje 
til å tilby innbyggerne sosial sikkerhet, synes foreløpig usikkert. Det som er sikkert er at Hizbullah på alle måter har utnyttet statens svake stilling fra I990 frem til i dag til å etablere seg selv som den sterkeste aktøren i landet, både politisk og militært. De fremste årsakene til at organisasjonen lar være å agitere for en islamsk stat er derfor ikke at Hizbullah er en tilhenger av pluralisme, som de selv hevder. Årsakene finnes snarere i to andre fakta: Hizbullahs opprinnelse som en motstandsbevegelse, og deres manøvrering siden borgerkrigens slutt - en manøvrering som har gitt dem en så sterk posisjon i Libanon at det er overflødig å kreve en islamsk stat. Gjennom et møysommelig arbeid sosialt, parlamentarisk og militært kan det se ut som at partiet har lyktes med en islamisering nedenfra, noe som taler mot maktbruk for å gjennomføre en islamsk orden. På mange måter befinner partiet seg nå i en vinn-vinn situasjon. På den ene siden representerer Hizbullah den demografisk sett største delen av befolkningen og ville derfor tjent på en avvikling av det sekterisk baserte valgsystemet, på den andre siden vil en opprettholdelse av systemet gjøre at partiet kan fortsette å utbygge og konsolidere de parallelle strukturene de allerede har etablert i det libanesiske samfunnet.

\section{$\cdot f \cdot$}

I Qasem, Naim: "Hizbullah: Al-Minhaj..al-Tajribah..al-Mustaqbal" [Hizbullah: Kursen, praksisen, fremtiden], Beirut: Dar al-Hadi 2004, s. 40-4I.

2 Alagha, Joseph: «The Shifts in Hizbullah's Ideology; Religious Ideology, Political Ideology and Political Program», Leiden: Amsterdam University Press 2006 s. 32.

3 Norton, Augustus Richard: «AMAL and the Shi'a. The Struggle for the Soul of Lebanon", Austin: University of Texas Press i987, s. 90-91.

4 Hamzeh, Ahmad Nizar: «In the Path of Hizbullah», New York: Syracuse Press 2004, s.24.
5 Alagha s. 36.

6 Hamzeh s. 30.

7 Ibid s. 3I.

8 Saad-Ghorayeb, Amal: «Hizbullah; Politics and Religion», London: Pluto Press 2002, s. 55-58 og Fuller, Graham E. and Francke, Rend Rahim: «The Arab Shi'a: The Forgotten Muslims», New York: Palgrave I999, s. 220.

9 An-Nahar 20. august 2008.

Io Deeb, Lara: «An Enchanted Modern; Gender and Public Piety in Shi'i Lebanon», Princeton: Princeton University Press 2006, s. 204-219. 